\title{
Bronchoscopic and percutaneous aspiration biopsy in the diagnosis of bronchial carcinoma cell type
}

\author{
RM RUDD, AR GELLERT, DAR BOLDY, PR STUDDY, MC PEARSON, DM GEDDES, \\ G SINHA
}

From the London Chest Hospital, London

\begin{abstract}
The cell type of bronchial carcinoma predicted from the results of bronchial biopsy at fibreoptic or rigid bronchoscopy or of percutaneous aspiration lung biopsy was compared with the type determined by histological examination of specimens obtained by thoracotomy, biopsy of an extrapulmonary metastasis, or necropsy in 180 cases. The rates of agreement with the final diagnosis were $95.7 \%$ for bronchial biopsy through the fibreoptic bronchoscope and $86.5 \%$ through the rigid bronchoscope. For percutaneous biopsy, which was usually carried out on tumours inaccessible to the bronchoscope, the rate of agreement was $61 \%$, significantly lower than by the other methods $(p<0.001)$. The diagnosis of oat-cell carcinoma by any technique was very reliable. Bronchial biopsy was more reliable than was percutaneous biopsy in diagnosing squamous-cell carcinoma. With any technique the commonest error was the incorrect diagnosis of squamous-cell carcinoma or adenocarcinoma as large-cell undifferentiated carcinoma.
\end{abstract}

Identification of the histological type of bronchial carcinoma is important because it is related to prognosis and response to treatment. Payne et al ${ }^{1}$ compared cell type prediction by cytology and biopsy techniques with the cell type determined by histological examination of thoracotomy or necropsy specimens. All bronchial biopsy specimens were obtained through the rigid bronchoscope. That study has recently been extended by the addition of results (including those based on fibreoptic bronchial biopsy specimens) from another centre. ${ }^{2}$ Biopsy samples obtained by rigid and fibreoptic bronchoscopy were not, however, analysed separately. Biopsy forceps passed through the fibreoptic bronchoscope are much smaller than those used with the rigid instrument. Consequently, samples are smaller and may also be crushed during withdrawal through the biopsy channel of the bronchoscope. For these reasons interpretation of the histological features of biopsy specimens obtained at fibreoptic bronchoscopy may be more difficult. The diagnosis of oat-cell carcinoma is particularly important because of the relatively poor results of surgery ${ }^{3}$ and the potential of combination chemotherapy and radiotherapy to relieve symptoms and even prolong survival. ${ }^{4}$ Payne et $a^{1}$ reported an accuracy of only

Reprints will not be available from the authors.
$50 \%$ for diagnosis of oat-cell carcinoma by bronchial biopsy compared with $80 \%$ by sputum cytology. Similar results for bronchial biopsy and sputum cytology, and a sensitivity of $40 \%$ for aspiration lung biopsy, have recently been quoted in a review based on various sources. ${ }^{5}$ After taking account of results from another centre, however, Payne et al revised their estimate for the accuracy of bronchial biopsy to $95 \% .^{2}$

The aim of this paper is to compare the predictive value of diagnosis of cell type by rigid and fibreoptic bronchial biopsy and percutaneous aspiration lung biopsy, with special reference to oat-cell carcinoma.

\section{Methods}

We examined medical records to identify all patients in the years 1978-81 from whom tissue obtained by lung resection, biopsy of mediastinal or peripheral lymph node or other extrapulmonary metastasis, or necropsy was available to confirm a diagnosis of bronchial carcinoma made by rigid or fibreoptic bronchoscopic bronchial biopsy or percutaneous aspiration lung biopsy.

Patients referred to the surgical department were usually examined initially by rigid bronchoscopy under general anaesthetic and those referred to the medical department usually by fibreoptic bronchoscopy under local anaesthetic. Percutaneous aspira- 
tion biopsy was performed either when the tumour was not detected bronchoscopically or when it was thought likely to be inaccessible by bronchoscopy. Some of the patients were investigated by more than one of the three techniques but histological evidence of carcinoma was found only by one biopsy technique in each case. This was the technique considered in this study. Cytological examination of sputum, bronchial aspirate, and bronchial brush biopsy specimens was not considered because numbers were inadequate.

Bronchial biopsies through the rigid bronchoscope were performed with Negus biopsy forceps, biopsies through an Olympus BFB3 fibreoptic bronchoscope with Olympus forceps. Bronchial biopsy specimens were fixed in formalin and embedded in paraffin, and sections were routinely stained with haematoxylin and eosin. Additional stains for mucin were done when required. Percutaneous lung biopsy was performed under radiological control with an 18-gauge Cook's tumour biopsy needle having a short bevel sharpened circumferentially. A portion of the biopsy specimen was placed in transport medium. The resulting suspension of cells was centrifuged and the cell fraction was then mixed with methylene blue for cytological examination. The rest of the specimen was fixed in formalin and embedded in paraffin, and sections were stained with haematoxylin and eosin for histological examination.

The following histological categories of bronchial carcinoma were recognised: squamous-cell carcinoma, adenocarcinoma, oat-cell and large-cell undifferentiated carcinomas, and mixed-that is, composed of two or more of these cell types. This classification is based on that proposed by the World Health Organisation in $1967 .^{\circ}$

Fourfold tables were analysed by the $\chi^{2}$ test with Yates's correction. Predictive values of tests were calculated with Bayes's theorem. ${ }^{57}$

\section{Results}

The definitive histological diagnosis was obtained from resected lung in 147 cases, biopsy of lymph node or other extrapulmonary metastasis in 25 cases, and necropsy in eight cases. Of the total of 180 patients, the cell type was squamous in 100 $(55.8 \%)$, adenocarcinoma in $30(16.7 \%)$, oat-cell in $29(16 \cdot 1 \%)$, large-cell undifferentiated in 16 $(8.9 \%)$, and mixed adenosquamous in $3(1.7 \%)$. One resected lung showed no evidence of carcinoma after a squamous tumour had been diagnosed by percutaneous biopsy.

The rate of agreement of cell type predicted by biopsy with definitive histological diagnosis was $95.7 \%$ for 47 bronchial biopsy specimens obtained by fibreoptic bronchoscopy, $86.5 \%$ for 74 bronchial biopsy specimens obtained by rigid bronchoscopy, and $61.0 \%$ for 59 aspirates obtained by percutaneous lung biopsy. There was no significant difference between the rates for the fibreoptic and the rigid bronchoscope but both were significantly higher than the rate for percutaneous biopsy $(\mathrm{p}<0.001$ in each case).

The sensitivity of a test is the percentage of patients with the disease in whom the test is positive. The specificity is the percentage of patients without the disease in whom the test is negative. The falsepositive rate is given by: 100 minus specificity and

Table 1 Operating characteristics of diagnostic techniques for determination of cell type of bronchial carcinoma*

\begin{tabular}{|c|c|c|c|c|c|}
\hline \multirow[t]{2}{*}{ Technique } & & \multicolumn{4}{|l|}{ Cell type } \\
\hline & & Squamous-cell & Adenocarcinoma & Oat-cell & Large-cell \\
\hline Fibreoptic bronchial biopsy & $\begin{array}{l}\text { No of patients } \\
\text { Sensitivity }(\%) \\
\text { Specificity }(\%) \\
\text { False positive }(\%) \\
\text { False negative }(\%)\end{array}$ & $\begin{array}{r}20 \\
95 \\
96 \\
4 \\
5\end{array}$ & $\begin{array}{r}3 \\
67 \\
100 \\
0 \\
33\end{array}$ & $\begin{array}{r}20 \\
100 \\
100 \\
0 \\
0\end{array}$ & $\begin{array}{r}4 \\
80 \\
98 \\
2 \\
20\end{array}$ \\
\hline Rigid bronchial biopsy & $\begin{array}{l}\text { No of patients } \\
\text { Sensitivity }(\%) \\
\text { Specificity }(\%) \\
\text { False positive }(\%) \\
\text { False negative }(\%)\end{array}$ & $\begin{array}{r}55 \\
89 \\
95 \\
5 \\
11\end{array}$ & $\begin{array}{r}8 \\
75 \\
97 \\
3 \\
25\end{array}$ & $\begin{array}{r}7 \\
86 \\
100 \\
0 \\
14\end{array}$ & $\begin{array}{r}4 \\
75 \\
91 \\
9 \\
25\end{array}$ \\
\hline Percutaneous aspiration biopsy & $\begin{array}{l}\text { No of patients } \\
\text { Sensitivity }(\%) \\
\text { Specificity }(\%) \\
\text { False positive }(\%) \\
\text { False negative (\%) }\end{array}$ & $\begin{array}{l}25 \\
58 \\
88 \\
12 \\
42\end{array}$ & $\begin{array}{r}19 \\
57 \\
100 \\
0 \\
43\end{array}$ & $\begin{array}{r}3 \\
100 \\
98 \\
2 \\
0\end{array}$ & $\begin{array}{r}8 \\
75 \\
67 \\
33 \\
25\end{array}$ \\
\hline
\end{tabular}

* Of three cases of mixed adenosquamous investigated by percutaneous biopsy, two were diagnosed as adenocarcinoma, and one as squamous carcinoma. These were counted as correct diagnoses. 
Table 2 Predictive value of biopsy techniques for determination of cell type of bronchial carcinoma

\begin{tabular}{|c|c|c|c|c|c|c|c|}
\hline \multirow[t]{2}{*}{ Cell type } & \multirow{2}{*}{$\begin{array}{l}\text { Estimated } \\
\text { frequency (\%) }\end{array}$} & \multicolumn{3}{|c|}{ Positive predictive value (\%) } & \multicolumn{3}{|c|}{ Negative predictive value (\%) } \\
\hline & & $\begin{array}{l}\text { Fibreoptic } \\
\text { bronchial } \\
\text { biopsy }\end{array}$ & $\begin{array}{l}\text { Rigid } \\
\text { bronchial } \\
\text { biopsy }\end{array}$ & $\begin{array}{l}\text { Percutaneous } \\
\text { biopsy }\end{array}$ & $\begin{array}{l}\text { Fibreoptic } \\
\text { bronchial } \\
\text { biopsy }\end{array}$ & $\begin{array}{l}\text { Rigid } \\
\text { bronchial } \\
\text { biopsy }\end{array}$ & $\begin{array}{l}\text { Percutaneous } \\
\text { biopsy }\end{array}$ \\
\hline $\begin{array}{l}\text { Squamous-cell } \\
\text { Adenocarcinoma } \\
\text { Oat-cell } \\
\text { Large-cell }\end{array}$ & $\begin{array}{l}48 \\
15 \\
16 \\
16\end{array}$ & $\begin{array}{r}96 \\
100 \\
100 \\
87\end{array}$ & $\begin{array}{r}94 \\
82 \\
100 \\
62\end{array}$ & $\begin{array}{r}82 \\
100 \\
90 \\
30\end{array}$ & $\begin{array}{r}95 \\
94 \\
100 \\
96\end{array}$ & $\begin{array}{l}90 \\
96 \\
97 \\
95\end{array}$ & $\begin{array}{r}69 \\
93 \\
100 \\
93\end{array}$ \\
\hline
\end{tabular}

the false-negative rate by: 100 minus sensitivity. In the context of this study sensitivity and specificity refer to the identification of cell type rather than to the diagnosis of malignancy-that is, sensitivity indicates the proportion of patients with a particular cell type correctly diagnosed as having that cell type, and specificity indicates the proportion of patients who did not have that cell type who were shown not to have that cell type. Table 1 shows these characteristics for each biopsy technique for each cell type.

The sensitivity and specificity of a test determine what proportion of patients with and without the disease will have positive and negative results. To interpret a result for an individual patient the clinician wishes to know its positive predictive valuethat is, if the test is positive what is the probability that the disease is present-and its negative predictive value-if the test is negative what is the probability that the disease is absent. These probabilities depend on the test characteristics and the prior estimate of the likelihood that the disease is present. A greater prior likelihood that a particular cell type is present leads to a higher positive predictive value of a biopsy specimen showing that cell type and a lower negative predictive value of a biopsy specimen not showing that cell type. Table 2 shows the predictive values for each biopsy technique for each cell type. Recent frequencies of histological types of bronchial carcinoma in patients presenting to the London Chest Hospital ${ }^{8}$ were used as the prior estimates of the probability that each cell type was present. These frequencies differ from those found in this study because the cases were selected on the grounds of availability of confirmatory histology.

\section{Discussion}

The histological type of bronchial carcinoma influences decisions about treatment. As fibreoptic bronchoscopy is superseding rigid bronchoscopy for diagnostic purposes it is important to know that it provides comparable diagnostic accuracy. The fibreoptic bronchoscope has been shown to have a greater biopsy range and a higher rate of histological confirmation of carcinoma when tumour is visible than the rigid bronchoscope. ${ }^{9}$ We are not aware of any previous studies which compare the reliability of fibreoptic and rigid bronchoscopic biopsies in diagnosing cell type.

The frequency of agreement with the definitive histological type was $\mathbf{9 5 . 7 \%}$ for biopsy specimens obtained by fibreoptic bronchoscopy and $86.5 \%$ for those obtained by rigid bronchoscopy. Payne et $a^{2}$ reported a rate of agreement of $92 \%$ in a series of biopsy specimens obtained by both techniques. The apparent superiority of fibreoptic bronchoscopy may be attributable to the larger number of biopsy samples usually taken during this procedure. The rate of agreement for percutaneous biopsy was significantly lower. Our result of $61 \%$ is very similar to the $62 \%{ }^{2}$ and $57 \%{ }^{10}$ reported from other centres. The difficulties in interpretation of aspiration biopsy samples have recently been reviewed. ${ }^{1011}$ The predictive value of a diagnosis of oat-cell carcinoma by any technique was very high. We found, like Payne et $a l,{ }^{2}$ that the commonest error was the incorrect diagnosis of squamous-cell carcinoma or adenocarcinoma as large-cell undifferentiated carcinoma.

Analysis of the operating characteristics and predictive value of diagnostic procedures facilitates their rational selection and interpretation. ${ }^{57}$ The exclusion of a diagnostic possibility requires a test with high sensitivity. The confirmation of a diagnosis requires a test with high specificity. The correct interpretation of a test result for an individual patient requires integration of knowledge of the test's characteristics with an estimate of the prior likelihood of the diagnosis. The application of the principles of quantitative reasoning to our results shows the usefulness of this method of analysis.

We would like to thank Mr JR Belcher for his helpful advice.

\section{References}

' Payne CR, Stovin PGI, Barker V, McVittie S, Stark JE. Diagnostic accuracy of cytology and biopsy in primary bronchial carcinoma. Thorax 1979;34:294-9. 
${ }^{2}$ Payne CR, Hadfield JW, Stovin PGI, Barker V, Heard B, Stark JE. Diagnostic accuracy of cytology and biopsy in primary bronchial carcinoma. J Clin Pathol 1981;34:773-8.

${ }^{3}$ Mountain CF. Clinical biology of small cell carcinoma: relationship to surgical therapy. Semin Oncol 1978;5:272-9.

${ }^{4}$ Greco FA, Richardson RL, Schulman SF, Stroup S, Oldham RK. Treatment of oat cell carcinoma of the lung: complete remissions, acceptable complications, and improved survival. $\mathrm{Br}$ Med J 1978;ii:10-1.

${ }^{5}$ Griner PF, Mayewski RJ, Mushlin AI, Greenland P. Selection and interpretation of diagnostic tests and procedures. Ann Intern Med 1981;94:553-600.

${ }^{6}$ Kreyberg L. Histological typing of lung tumours. Geneva: World Health Organisation, 1967.
${ }^{7}$ McNeil BJ, Keeler E, Adelstein SJ. Primer on certain elements of medical decision making. $N$ Engl J Med 1975;293:211-5.

${ }^{5}$ Caplin M. Tumours of the lung: pathology and clinical presentations. In: Emerson P. Thoracic medicine. London: Butterworths, 1981:805-30.

9 Webb J, Clarke SW. A comparison of biopsy results using rigid and fibreoptic bronchoscopes. Br J Dis Chest 1980;74:81-3.

${ }^{10}$ Flower, CDR, Verney, GI. Percutaneous needle biopsy of thoracic lesions-an evaluation of $\mathbf{3 0 0}$ biopsies. Clin Radiol 1979;30:215-8.

"Tao LC, Perason FG, Delarue NC, Langer B, Saunders DE. Percutaneous fine-needle aspiration biopsy: its value to clinical practice. Cancer 1980;45:1480-5. 